\title{
PENGEMBANGAN NILAI-NILAI INTEGRITAS DAN IDENTITAS NASIONAL DARI PERSPEKTIF PENDIDIKAN
}

\section{Parji *}

\begin{abstract}
Abstrak
Nilai-nilai integritas dan identitas nasional Indonesia dewasa ini mengalami tantangan yang berat baik dari pengaruh eksternal maupun internal, dan nilai-nilai tersebut cenderung mengalami erosi dan degradasi. Dalam konteks seperti ini, dunia pendidikan, termasuk para pendidik memiliki peran strategis dalam mempertahankan sekaligus mengembangkan nilai-nilai integritas dan identitas nasional, karena pendidikan memiliki fungsi enkulturasi dan sosialisasi nilai kepada peserta didik agar mampu membangun dirinya dan bersama-sama dengan lingkungannya membangun masyarakat dan bangsa. Untuk itu perlu dikembangkan paradigma baru pendidikan yang dapat menjaga nilai-nilai tersebut tumbuh dan berkembang dengan baik, dan dalam hubungannya dengan guru, maka diperlukan guru-guru yang profesional dan mempunyai kompetensi yang komprehensif.
\end{abstract}

\section{Kata Kunci : Nilai Integritas, Identitas Nasional, Pendidikan}

\section{Pendahuluan}

Negara Kesatuan Republik Indonesia (NKRI) lahir dari sebuah proses sejarah yang panjang. Dimulai dari jaman kerajaan, masa kolonalisme, kesadaran akan nasionalisme-patriotisme yang dimulai 1908 (Boedi Oetomo), Sumpah Pemuda (1928), dan memncapai puncaknya pada Proklamasi Kemerdekaan RI pada tanggal 17 Agustus 1945. Sejarah panjang perjuangan bangsa itu telah melahirkan idealisme bangsa dalam bangun-an negara-bangsa (nation state) yang dilandasi oleh rasa senasib seperjuangan dan keinginan yang kuat untuk mencapai cita-cita bersama dalam rajutan tujuan nasional sebagaimana termaktub dalam Pembukaan UUD 1945, yaitu melindungi segenap bangsa dan seluruh tumpah darah Indonesia, memajukan kesejahteraan umum

* Parji adalah Dosen Pendidikan Pancasila dan Kewarganegaraan IKIP PGRI Madiun; Jl Setiabudi 85 Madiun. 
mencerdaskan kehidupan bangsa, dan ikut melaksanakan ketertiban dunia berdasarkan perdamaian abadi.

Sebagai sebuah negara-bangsa yang lahir dari proses perjuangan yang panjang tidak diragukan lagi bahwa masyarakat dan bangsa Indonesia sesungguh-nya memiliki nilai-nilai intergritas dan identitas nasional yang sangat kuat. Bahkan nilai-nilai intergritas dan nilai-nilai identitas bangsa itu dengan sangat cerdas oleh the founding fathers (para pendiri bangsa-negara), diangkat dan mengkristal menjadi dasar negara Pancasila. Pancasila disepakati karena dapat menampung kemajemukan bangsa. Pancasila lahir karena diinspirasi oleh ide-ide besar dunia dan menyuarakan kepentingan harkat martabat manusia, serta keadilan serta pentingnya kesadaran dalam hidup berbangsa dan bernegara. Pancasila dijadikan idealisme dalam berbangsa dan bernegara karena meletakkan kehidupan keberagaman yang penuh toleransi.

Kini sudah 65 tahun Indonesia merdeka. Dunia berubah demikian cepat dan dinamis, ditandai revolusi teknologi informasi komunikasi yang membawa dampak pada perubahan sosial yang luar biasa, termasuk dalam tatanan hidup antar bangsa dan goyahnya tatanan value (nilainilai) dan masyarakat. Alvin Tofler, seorang futurolog terkenal menggunakan istilah "kejutan masa depan" (future shock) untuk menggambarkan situasi sekarang yang membuat kita terlempar pada suatu kondisi di mana kita mengalami tekanan-tekanan yang mengguncangkan dan hilangnya orientasi individu disebabkan kita dihadapkan dengan terlalu banyak perubahan dalam waktu yang terlalu singkat. Itulah situasi yang dialami juga oleh masyarakat dan bangsa Indonesia. Perubahan-perubahan berskala besar dan cepat ternyata kita respon secara lambat (Soyomukti, 2008: 41).

Realitas global tersebut yang kemudian populer dengan istilah "globalisasi" mau tidak mau, suka tidak suka, kita harus hadapi karena kita tidak bisa menghindar dari arus besar globalisasi. Globalisasi adalah arus utama yang membawa dampak mahahebat terhadap ruang waktu yang mengalami percepatan atau terjadinya dalam bahasa Anthony Giddens - time space distenziation. Tentu saja interaksi manusia dengan teknologi, manusia dengan manusia lain, semakin intensif: makna baru didapat dari obyektivitas baik rasional maupun irasional karena perkembangan baris material, IPTEK, yang terus berubah (Soyomukti, 2008: 43).

Bagaimanakah perubahan yang besar dan cepat tersebut bila dikaitkan dengan nilai-nilai intergritas dan identitas nasional Indonesia? Kemudian bagaimanakah kita harus menghadapi dan menyikapi, adalah pertanyaan besar kita saat ini. Yang jelas sebagaimana disampaikan Sztompka (2007:112), globalisasi menimbulkan bahaya dan harapan. Proses globalisasi yang meliputi semua aspek kehidupan modern (ekonomi, politik, dan kultural) tercermin dalam kesadaran sosial. Cara orang memahami dunia, dunia lokal mereka sendiri dan dunia 
keseluruhan, mengalami perubahan sangat besar.

Fenomena maraknya gerakangerakan separatis, terorisme, anarkisme, demokrasi kebablasan, otonomi yang disalahartikan barangkali adalah penanda bahwa nilai-nilai integrasi kita sebagai bangsa sedang mendapat ujian. Sedangkan gaya hidup yang cenderung hedonismaterialis dan kapitalis telah mendorong perilaku yang korup, menghalalkan segala cara, jauh dari kesederhanaan dan ketulusan bisa jadi menjadi penanda bahwa sifatsifat dan karakteristik kita (identitas) nasional kita mulai goyah dan menglami erosi yang cukup dalam.

\section{Nilai-Nilai Integritas dan Identitas Nasional}

\section{Dalam Dictionary of Sosciology} and Rekted Seiences dikemukakan bahwa nilai adalah kemampuan yang dipercayai yang ada pada suatu benda untuk memuaskan manusia. Nilai adalah kualitas dari sesuatu baik lahir maupun batin. Dalam kehidupan manusia, nilai dijadikan landasan, alasan, atau motivasi dalam bersikap dan bertingkah laku baik disadari maupun tidak. Nilai berbeda dengan fakta dimana fakta dapat diobservasi melalui verifikasi empiris, sedangkan nilai bersifat abstrak yang harus dapat dipahami, dipikirkan, dimengerti dan dihayati oleh manusia. Nilai berkaitan juga dengan harapan, cita-cita, keinginan dan sejak sesuatu pertimbangan internal (batiniah) manusia (Kaelan, 2001:179).
Integritas dapat dipahami sebagai penggabungan dari beberapa kelompok yang terpusat menjadi satu kesatuan yang mempunyai tujuan dan cita-cita yang sama (Andisuhandi, 2008). Dalam hukum internasional, setiap negara yang berdaulat memiliki integritas teritorial, artinya wilayah negara itu tidak boleh diganggu gugat oleh negara-negara lain. Setiap negara yang berdaulat mempunyai hak sepenuhnya untuk menuntut agar negara-negara asing tidak mecoba melakukan pelanggaran terhadap kedaulatannya baik di bidang kehakiman, maupun militer, pemerintahan dan sebagainya.

Sedangkan identitas nasional, secara etimologis berasal dari kata "identitas" dan "nasional". Kata identitas (Inggris: identity) secara harfiah artinya ciri, tanda atau jatidiri yang melekat pada seseorang, kelompok atau sesuatu sehingga membedakan dengan yang lain. Dengan demikian, identitas berarti ciri-ciri, tanda-tanda atau jati diri yang dimiliki seseorang, kelompok, masyarakat bahkan suatu bangsa sehingga identitas itu bisa membedakan dengan yang lain. Kata nasional merujuk pada konsep kebangsaan. Nasional menunjuk pada kelompok-kelompok persekutuan hidup manusia yang lebih besar dari sekedar pengelompokan berdasarkan ras, agama, budaya, bahasa, dan sebagainya. Oleh karena itu, identitas nasional lebih merujuk pada identitas bangsa dalam pengertian politik (political unity).

a. Sektor-sektor Integrasi Nasional

Apabila kita analisis, ada beberapa faktor yang dapat menjadi 
pendorong dan penopang integrasi nasional :

1) Sektor sosial-budaya

Bagi bangsa Indonesia, sektor sosial merupakan sektor utama dalam meningkatkan integrasi nasional. Secara historis ada faktor-faktor penting bagi pembentukan bangsa Indonesia, yaitu :

- Adanya persamaan nasib, yaitu penderitaan bersama di bawah, penjajahan bangsa asing yang lebih kurang selama 350 tahun.

- Adanya keinginan bersama untuk merdeka, melepaskan diri dari belenggu penjajahan.

- Adanya kesatuan tempat tinggal, yaitu wilayah nusantara yang membentang dari Sabang sampai Merauke. - Adanya cita-cita bersama untuk mencapai kemakmuran dan keadilan sebagai suatu bangsa.

Budaya bangsa yang sangat majemuk dengan berbagai adatistiadat, suku, ras, bahasa daerah dan lain-lain juga menjadi kekayaan yang luar biasa, bisa dikelola dengan baik.

2) Sektor Ekonomi

Persoalan ekonomi merupa-kan sektor utama yang sangat sensitif. Banyaknya ketimpangan ekonomi baik kemiskinan, penggangguran, ketimpangan modal menjadi titik rawan yang bisa merusak integrasi nasional. Gejolak-gejolak sosial yang muncul di masyarakat seringkali dipicu oleh kecemburuan sosial yang meningkat dan menimbulkan eskalisi politik yang mudah disusupi.

3) Sektor Politik

Perkembangan politik di tanah air mengalami pasang surut yang begitu dinamis. Seiring dengan reformasi 1998, kehidupan politik
Indonesia telah mengalami lompatan yang seringkali justru menjadikan kita sendiri tidak siap menjalankan demokrasi yang dilandasi oleh etika politik. Hingar-bingar politik telah melahirkan politikus yang seringkali hanya bernilai kepentingan golongan, kelompok, bahkan pribadi yang jauh dari kepentingan negara dan bangsa. Bisa jadi kita telah melahirkan politikus-politikus, tetapi miskin negarawan.

4) Sektor Keamanan

Faktor keamanan begitu penting dalam rangka men-ciptakan stabilitas bangsa dan negara. Negara yang sama juga merupakan salah satu faktor pertimbangan investor untuk menanamkan modalnya di Indonesia. Politik tentara yang menjaga mutu dan berdiri di atas kepentingan masyarakat, bangsa dan negara adalah suatu pilihan tepat untuk terus diaktualisasikan sesuai tuntutan zaman.

b. Bentuk-bentuk Integrasi Nasional Beberapa bentuk identitas nasional Indonesia yang perlu terus dipelihara dan ditingkatkan adalah sebagai berikut :

1) Bahasa nasional atau bahasa persatuan, yaitu bahasa Indonesia.

Bahasa Indonesia berawal dari rumpun bahasa Melayu yang dipergunakan sebagai bahasa pergaulan yang kemudian diangkat sebagai bahasa persatuan pada tanggal 28 Oktober 1928. Bangsa Indonesia sepakat bahwa bahasa Indonesia merupakan bahasa nasional sekaligus sebagai identitas nasional Indonesia.

2) Dasar falsafah negara, yaitu Pancasila. 
Berisi lima nilai dasar yang dijadikan sebagai dasar filsafat dan ideologi dari negara Indonesia. Pancasila merupakan identitas nasional yang berkedudukan sebagai dasar negara dan ideologi nasional Indonesia.

3) Lagu Kebangsaan yaitu Indonesia Raya.

Indonesia Raya sebagai lagu kebangsaan pada tanggal 28 Oktober 1928 dinyanyikan untuk pertama kali sebagai lagu kebangsaan negara.

4) Lambang Negara, yaitu Garuda Pancasila.

Garuda adalah burung khas Indonesia yang dijadikan lambang negara.

5) Semboyan negara, yaitu Bhinneka Tunggal Ika

Bhinneka Tunggal Ika artinya berbeda-beda tetapi tetap satu. Menunjukkan kenyataan bahwa bangsa kita heterogen, namun tetap berkeinginan untuk menjadi satu bangsa yaitu bangsa Indonesia.

6) Bendera negara, yaitu Sang Merah Putih.

Warna merah berarti berani dan putih berarti suci. Lambang merah putih sudah dikenal pada masa kerajaan di Indonesia yang kemudian diangkat sebagai bendera negara. Bendera warna merah putih dikibarkan pertama kali pada tanggal 17 Agustus 1945, namun telah ditunjukkan pada peristiwa Sumpah Pemuda.

7) Konstitusi (hukum dasar) negara, yaitu UUD 1945.

Merupakan hukum dasar tertulis yang menduduki tingkat-an tertinggi dalam tata urutan perundangan dan dijadikan sebagai pedoman penyelenggaraan bernegara.

8) Bentuk Negara Kesatuan Republik Indonesia yang berkedaulatan rakyat. Bentuk negara adalah kesatuan, sedang bentuk pemerintahan adalah Republik. Sistem politik yang digunakan adalah sistem demokrasi (kedaulatan rakyat). Saat ini identitas Negara Kesatuan Republik Indonesia yang berkedaulatan rakyat disepakati untuk tidak ada perubahan.

9) Konsepsi Wawasan Nusantara.

Sebagai cara pandang bangsa Indonesia mengenai diri dan lingkungannya yang serba beragam dan memiliki nilai strategis dengan mengutamakan persatuan dan kesatuan bangsa, kesatuan wilayah dalam penyelenggaraan kehidupan bermasyarakat, ber-bangsa, dan bernegara untuk mencapai tujuan nasional.

10) Kebudayaan daerah yang telah diterima sebagai kebudayaan nasional.

Berbagai kebudayaan dari kelompok-kelompok bangsa Indonesia yang dimiliki cita rasa tinggi, dapat dinikmati dan diterima oleh masyarakat luas merupakan kebudayaan nasional. Kebudayaan nasional pada dasarnya adalah puncak dari kebudayaan daerah.

Tumbuh dan disepakatinya beberapa identitas nasional Indonesia itu sesungguhnya telah diawali dengan adanya kesadaran politik bangsa Indonesia sebelum bernegara. Hal demikian sesuai dengan ciri dari pembentukan negara model mutakhir. Kesadaran politik itu adalah tumbuhnya semangat nasionalisme (semangat kebangsaan) sebagai 
gerakan me-nentang penjajahan dan mewujudkan negara Indonesia. Dengan demikian, nasionalisme yang tumbuh kuat dalam diri bangsa Indonesia turut mem-permudah terbentuknya identitas nasional Indonesia.

\section{Peran Pendidikan}

Tujuan utama pendidikan adalah pengembangan kepribadian. Tugas pendidikan adalah mengantarkan generasi masa depan mampu merengkuh masa depannya sendiri serta tidak tercerabut dari kemampuannya dalam menghadapi kontradiksi alam yang selalu mengalami perubahan. Kemendiknas merumuskan visi pendidikan nasional yaitu insan yang cerdas dan kompetitif.

Dikaitkan dengan meningkatkan nilai-nilai integritas dan identitas nasional jelas bahwa pendidikan mempunyai peran yang sangat strategis. Dalam hal ini peran pendidikan harus dipandang baik dari sudut pendidikan informal, pendidikan formal, maupun pendidikan non formal.

\section{a. Perlunya paradigma baru pendidikan}

Dalam menghadapi perkembangan sosial yang begitu cepat, UNESCO berusaha mengakomodasi tuntutan sosial pendidikan dengan menegaskan pilar-pilar yang diakomendasikan dalam dunia pendidikan, yaitu learning to know, learning to do, learning to be, learning to live together.
Di Indonesia pilar-pilar tersebut belum dapat ditegakkan. Padahal prinsip pendidikan tersebut sangat komprehensif dan jika dapat diterapkan dengan benar dan konsisten akan mampu menjadi unsur yang selain menguasai informasi dan ilmu pengetahuan juga memiliki tanggungjawab (sense of responsibility) dan keperdulian sosial yang tinggi (Suryomukti, 2008: 31).

b. Perlu pendidikan ber-perspektif global

Pengembangan nilai-nilai integritas dan identitas nasional saat ini tidak bisa menafikan kondisi dunia yang semakin berubah. Ada kecenderungan bahwa negara-negara di dunia juga melakukan pola-pola integrasi internasional dengan membentuk persekutuan-persekutuan dan korporasi-koporasi global, misalnya: IMF, AFTA, ASEAN, MEE. Sudah barang tentu kita sebagai bangsa harus cerdas memilah dan memilih mana yang bisa memberi kontribusi pada bangsa dan mana yang bisa menghancurkan kepentingan bangsa (nasional). Salah satu tantangan berat kita dalam kompetisi global itu ialah rendahnya kualitas SDM (Sumber Daya Manusia). Rendahnya kualitas SDM itu pula yang menyediakan daya saing kita sebagai bangsa rendah.

c. Perlu pendidikan berperspektif lingkungan

Secara kasat mata dapat kita lihat bahwa Indonesia dan dunia sedang menghadapi permasalahan lingkungan yang akut. Kerusakan hutan yang begitu parah, fenomena banjir, dan tanah longsor, serta pemanasan global akan menjadi per-masalahan 
serius Indonesia dan dunia. Indonesia sebagai salah satu paru-paru dunia sudah seharusnya menunjukkan jati diri sebagai bangsa yang mencintai lingkungan. Identitas kita sebagai bangsa seharusnya tidak tergerus oleh perilaku tamak dengan melakukan pembalakan liar dan illegal loging.

d. Pentingnya Pendidikan Moral dan Budi Pekerti

Kita semua merasakan betapa permasalahan moral dan budi pekerti akhir-akhir ini sangat memprihatinkan. Gejala dekonsensi moral tumbuh subur seiring melemahnya ikatanikatan moral dalam masyarakat. Zuriah (2007:10) mengatakan lebihlebih lagi di era globalisasi yang berada dalam dunia yang terbuka, ikatan-ikatan nilai-nilai moral mulai melemah. Masya-rakat mengalami multikrisis yang dimensional, dan krisis yang dirasakan sangat parah adalah krisis nilai-nilai moral.

Setidaknya ada 4 (empat) pertimbangan utama mengapa penguatan pendidikan moral dan budi pekerti begitu mendesak: Melemahnya ikatan keluarga, keluarga yang secara tradisional merupakan guru pertama dari sikap enak, mulai kehilangan fungsinya; (2) Kecenderungan negatif kehidupan remaja dewasa ini. Fenomena tawuran pelajar, keterlibatan dalam NAPZA, seks bebas, dan tingkah laku menyimpang lainnya menjadi bukti bahwa kehidupan remaja kita sangat mengkhawatirkan; (3) Minimnya tokoh panutan dalam masyarakat. Gaya ke-hidupan pemimpin masyarakat yang cenderung hedonis, korupsi, dan kolutif turut mem- berikan andil ambruknya nilai-nilai moral dalam masyarakat dan (4) Kesadaran tidak seimbangan kehidupan antara kemajuan dan kedamaian tampaknya mulai disadari oleh banyak bangsa.

e. Pentingnya pendidikan multikultural

Sudah menjadi kodrat bahwa kita adalah bangsa yang majemuk, baik dari sisi agama, adat istiadat, etnik, bahasa daerah, dan budaya daerah. Suatu persoalan serius yang dihadapi Indonesia hingga hari ini ialah benturan dan konflik yang disebabkan oleh faktor pluralitas multikultural Contoh aktual ialah kasus Mbah Priok di Jakarta, munculnya aliran-aliran sesat dalam masyarakat, kasus Pilkada di Mojokerto.

Dalam konteks Indonesia yang sarat kamajemukan itulah, menurut Masa Asy'arie (dalam Suwandi, 2010) pendidikan multikultural menjadi sangat strategis untuk dapat mengelola kemajemukan secara kreatif sehingga konflik yang muncul sebagai dampak dari transformasi dan reformasi sosial dapat dikelola secara cerdas dan menjadi bagian dari pencerahan kehidupan bangsa ke depan.

Menurut Naim \& Sauqi (2008:191) pendidikan pluralis multikultural adalah pendidikan yang memberikan penekanan terhadap proses penanaman cara hidup yang saling menghormati, tulus, dan toleran terhadap keanekaragaman budaya yang hidup di tengah-tengah masyarakat dengan tingkat pluralitas yang tinggi. Dengan pendidikan pluralitas multikultural dihadapkan 
akan lahir kesadaran dan pemahaman secara luas yang diwujudkan dalam sikap yang toleran, bukan sikap yang kaku, eksklusif dan menafikan eksistensi kelompok lain maupun mereka yang berbeda, apapun bentuk perbedaan-nya.

\section{Peran Strategis Pendidik}

Dalam pengembangan nilai-nilai integritas dan identitas nasional pada era globalisasi peran pendidik (gurudosen) menjadi amat penting. Pendidik sebagai ujung tombak dalam pendidikan dituntut mempunyai kompetensi yang komprehensif yang meliputi: kompetensi pedagogik, kompetensi kepribadian, kompetensi sosial dan kompetensi profesional.

Menurut Mery Field (dalam Suryo Mukti, 2008:53) ada tiga syarat yang harus dimiliki guru dalam mengembangkan pendidikan yang berperspektif global: kemampu-an konseptual, pengalaman lintas budaya, dan keterampilan pedagogis.

Kemampuan konsseptual berkenaan dengan peningkatan pengetahuan guru dalam konteks isu-isu global. Guru harus memiliki wawasan tentang isu, dinamika, sejarah, dan nilai-nilai global agar mereka memiliki keterampilan mengapresiasi persamaan dan perbedaan budaya dalam masyarakat dunia sekaligus membangun suasana belajar yang dinamis agar siswa mampu merespon isu-isu lokal dalam kaitannya dengan masalah global.

Syarat berikutnya ialah pengalaman lintas budaya. Syarat ini belum banyak dimiliki oleh guru
Indonesia. $\mathrm{Di}$ kalangan dosen kondisinya masih lebih baik. Sedangkan syarat ketiga keterampilan pedagogis dalam perspektif global menyangkut metode mengajar yang tepat agar peserta didik dapat memahami suatu masalah dalam konteks yang luas dan komprehensif.

Dalam konteks pendidikan moral, maka seorang pendidik atau guru haruslah menjadi model, sekaligus menjadi mentor dari peserta didik dalam mewujudkan nilai-nilai moral pada kehidupan disekolah dan masyarakat. Dalam hal ini banyak yang bisa dilakukan guru seperti: menciptakan suasana demokratis, mengembangkan refleksi moral, mengajarkan resolusi konflik dan tentu juga menumbuh-kan budaya kerjasama (Zuriah, 2008:107-108).

Dikaitkan dengan pendidikan multikultural, Sarwiji Suwandi (2010:19) mengatakan bahwa guru juga dituntut untuk senantiasa berupaya meningkatkan pemahaman dan kemampuan komunikasi lintas budaya para siswa. Upaya itu antara lain dengan memilih, menyediakan, dan menggunakan materi ajar yang berdasarkan multikultural. Perlu dihindari buku-buku pelajaran yang bermuatan rasis dan provokatif terhadap munculnya pertentangan yang destruktif, dan sebaliknya perlu dipilih dan digunakan buku-buku pelajaran yang peka akan nilai-nilai keagamaan, nilai-nilai multikultural.

Secara umum, Soeparno dan Kamdi (2009:14) menganjurkan perlunya pemutakhiran pengetahuan atau kemampuan guru dalam bidang studi. Jelasnya, pengetahuan subjectmofler secara positif berdampak pada 
kinerja guru, meskipun hal ini bukan satu-satunya variabel penentu. Selain itu, guru perlu memperluas taxonomi tujuan belajar. Taxonomi Bloom yang meng-klarifikasi hasil pembelajaran menjadi tiga ranah yaitu: (1) Kognitif, (2) Sikap (efektif), dan (3) Psikomotorik.

Belakangan ini semakin disadari pentingnya analisis tujuan belajar yang menggunakan tinjauan taxonomi berdasarkan jenis ke-cakapan hidup (life skills), yakni (1) kecakapan spesifik (specific skills/hard skills) dan (2) kecakapan generik (generic skills/soft skills) (Soeparno dan Kamdi, 2009:18).

Dengan demikian, guru atau pendidik pada era globalisasi ini memang dituntut mempunyai kompetensi yang baik dan komprehensif, mengingat tantangan-tantangan kehidupan yang semakin kompleks. Pendidik dituntut menjadi agen pembebasan, perubahan sekaligus pencerahan.

\section{Penutup}

Dari pembahasan dan uraian diatas dapat ditarik simpulan bahwa:

1. Secara historis masyarakat dan bangsa Indonesia telah memiliki nilainilai integritas dan identitas nasional. Nilai-nilai itu terimplementasi dalam kehidupan bermasyarakat, berbangsa dan bernegara serta dimatangkan oleh pengalaman sejarah perjuangan bangsa yang begitu panjang.

2. Pada era globalisasi, nilai-nilai integritas dan identitas nasional Indonesia mengalami tantangan yang berat baik dari pengaruh eksternal maupun internal, sektor-sektor integrasi baik dalam bidang sosial budaya, ekonomi, politik dan keamanan seringkali mengalami pasang surut seiring dengan dinamika nasional dan global. Nilai-nilai identitas nasional dalam dekade belakang-an juga menghadapi erosi dan degradasi yang begitu serius.

3. Peran dunia pendidikan, termasuk para pendidik amat strategis dalam mempertahankan sekaligus mengembangkan nilai-nilai integritas dan identitas nasional yang kita miliki. Karena itu, pendidikan dengan perspektif globalisasi lingkungan, moral dan multikultural dalam koridor paradigma baru pendidikan tentu amat diperlukan. Terkait dengan guru, maka diperlukan guruguru yang mempunyai kompetensi yang baik dan komprehensif. 


\section{Daftar Pustaka}

C. Asri Budiningsih, 2008, Pembelajaran Moral, Jakarta: Rineka Cipta.

Dwi Winarno, 2006, Paradigma Baru Pendidikan Kewarganegaraan Di Perguruan Tinggi, Jakarta : Bumi Aksara.

Kaelan, 2001, Pendidikan Pancasila, Yogyakarta: Paradigma

Ngainum Naim \& Achmad Sauqi, 2008, Pendidikan Kultural Konsep dan Aplikasi, Yogyakarta: Ar Ruzz Media.

Soyomukti, Nurani, 2008, Pendidikan Perspektif Globalisasi, Yogyakarta: Ar Ruzz Media

Suwandi, Sarwiji, 2010, Pemantapan Peran Bahasa Indonesia Sebagai Wahana Integrasi Bangsa Dalam Konteks Pendidikan Multikultural, Surakarta: UNS Press.

Suparno dan Waras Kamdi, 2009, Pengembangan Profesionalitas Guru, Malang: UM

Sztompka, Pior, 2002, Teori Perubahan Sosial, Jakarta: Renika Cipta.

Zariah, Nurul, 2007, Pendidikan Moral Dan Budi Pekerti Dalam Perspektif Perubahan, Jakarta: Bumi Aksara 